\title{
The impact of an integrated micro-credit programme on women's empowerment and fertility behavior in rural Bangladesh
}

\author{
Fiona Steele \\ Sajeda Amin \\ Population Council \\ Ruchira Tabassum Naved
}

Follow this and additional works at: https://knowledgecommons.popcouncil.org/departments_sbsr-pgy

Part of the Demography, Population, and Ecology Commons, Family, Life Course, and Society Commons, and the International Public Health Commons How does access to this work benefit you? Let us know!

\section{Recommended Citation}

Steele, Fiona, Sajeda Amin, and Ruchira Tabassum Naved. 1998. "The impact of an integrated micro-credit programme on women's empowerment and fertility behavior in rural Bangladesh," Policy Research Division Working Paper no. 115. New York: Population Council. 


\section{The Impact of an Integrated Micro-credit Program on Women's Empowerment and Fertility Behavior in Rural Bangladesh}

Fiona Steele Sajeda Amin Ruchira T. Naved 


\title{
The Impact of an Integrated Micro-credit Program on Women's Empowerment and Fertility Behavior in Rural Bangladesh
}

\author{
Fiona Steele \\ Sajeda Amin \\ Ruchira T. Naved
}

Fiona Steele is Lecturer, Department of Statistics, London School of Economics and Political Science. Sajeda Amin is Associate, Policy Research Division, Population Council. Ruchira T. Naved is Independent Consultant, Save the Children, USA, Dhaka, Bangladesh.

The authors would like to thank Save the Children, USA for permission to use the Empowerment Survey data. 


\begin{abstract}
This paper examines the impact of participation in women's savings and credit groups organized by Save the Children USA on women's empowerment, contraceptive use, and fertility in a rural area of Bangladesh. The data are drawn from a panel survey conducted in 1993, shortly before the groups were formed, and in 1995 after interventions began. This quasi-experimental design enables us to identify the characteristics of women who chose to join savings groups. The findings show that those who joined tend to be more educated and more socially independent than are women who did not. Thus, to control for selection bias, preintervention measures of empowerment are taken into consideration in the analyses of the impact of savings groups on 1995 levels of empowerment and fertility behavior. The analysis shows positive impacts of the credit program on aspirations with regard to children's education, age at marriage, and use of modern contraceptives.
\end{abstract}

This material may not be reproduced in any form without written permission from the authors. 


\section{INTRODUCTION}

This paper uses unique panel-study data from rural Bangladesh to explore how participation in savings and credit schemes affects women's contraceptive use and fertility. Most studies of women's credit-group participation and fertility outcomes are based on cross-sectional data that do not adequately control for the problem of self-selection of more independent women or those of lower fertility into credit groups. If those women who are more empowered than others and women who are prior contraceptive users are more likely to join credit groups, higher contraceptive use among credit-group participants compared with nonparticipants cannot be attributed to program impact alone. The data from this study on indicators of empowerment and measures of fertility from a time period before women joined such groups allows us to characterize the selectivity of credit programs and measure whether contraceptive use is higher among those who join, controlling for selectivity of programs.

Micro-credit schemes are thought to be potent agents of social change in impoverished settings where women lack access to resources. In Bangladesh, the first experiments with group-based lending were conducted by Grameen Bank in 1978, and this approach has proved to be an effective mechanism for offering collateral- free credit and ensuring high repayment rates. More than three million poor Bangladeshi women are estimated to have been recipients of small loans in mid-1995 (Sobhan, 1995). Programs for similar schemes are expanding rapidly, not just in Bangladesh, but in other developing countries where women are similarly disadvantaged.

A number of causal mechanisms can exist through which women's participation in micro-credit schemes can affect their fertility. To understand why some of these factors have been proposed, a short description of how a typical scheme works may be useful. Most credit programs in rural Bangladesh, including the one studied here, offer collateral-free small loans to poor women. To become eligible, women have first to form a small group in their village. Loans are given 
to individuals based on the feasibility of a proposed repayment schedule, usually a two-year period of weekly installments. Each group meets once a week with a representative of a development organization in charge of repayments and granting new loans. The groups are guarantors of loans to individual members and are jointly responsible if a member defaults on a loan. Group meetings also serve as opportunities for other interventions, such as adult literacy programs.

A primary function of offering women credit in this way is to enhance their economic status. Credit enables women to earn extra income through which they can gain greater financial autonomy. Therefore, credit can increase the opportunity cost of childbearing by increasing the economic returns on women's time. Such a mechanism is more likely to work according to design if the credit received is in fact invested in women's own enterprises.

Several studies suggest that access to credit empowers women by increasing their autonomy and decisionmaking ability within the household. Women are thereby able to attain their fertility goals by using contraceptives to limit fertility (Schuler and Hashemi, 1994). However, most programs cannot ensure that women retain control over the money they are lent. Women commonly hand over control of the loan or invest it in a family enterprise (Goetz and Gupta, 1996). When receiving credit allows a woman to engage in an independent economic enterprise, it is not difficult to see how access to credit would enhance her financial independence. However, even when a loan is invested in a joint enterprise with other household members, a woman may become more involved in household decisionmaking because she becomes a channel through which new resources can flow into the household and because she is ultimately responsible for loan repayment, even if she is not solely responsible for the economic enterprise in which the loan is invested (Amin and Pebley, 1994). Such changes can be particularly empowering in a setting such as rural Bangladesh where women rarely engage in activities that generate income directly (Amin, 1997). 
Membership in a credit program can promote women's greater interaction with the outside world. The role of social interaction in promoting the diffusion of an innovative behavior such as contraception is well documented (Bongaarts and Watkins, 1996; Montgomery and Casterline, 1993). Montgomery and Chung (1998) found similar effects of Korean mothers' clubs on contraceptive uptake. Social networks can promote access to new information as well as provide evaluative information about the consequences of behavior. Women's likelihood of using contraceptives may be enhanced when they join a credit group, because related activities such as attending meetings can increase their social interaction.

In addition to its impact on contraceptive behavior, social interaction may also encourage changes in fertility aspirations and women's general world view. Some of these attitudinal changes are actively promoted by the development organizations that are responsible for delivering credit. Others may be by-products of the greater awareness that results from the interactions of a group's members.

Finally, macro-level changes may be brought about by the expansion of credit to large numbers of women. In Bangladesh, where several million women are now credit beneficiaries, women's credit is a major source of cash infusion for village economies. When fertility was high in the 1970s, the absence of strong financial markets that could allow households to save and provide for old-age security was thought to be a major impediment to the reduction of fertility (Cain, 1985). Although women's credit schemes in Bangladesh remain limited to shortterm loans and not the long-term pension schemes that can serve as alternativerisk insurance mechanisms for children, nevertheless, the advent of a credit program in a rural area can bring about some change within a village's financial markets that affects the inhabitants' sense of security and vulnerability.

Hypotheses about the potential contribution of credit programs are explored here with data collected from Nasirnagar thana (region) in the district of Brahmanbaria in eastern Bangladesh in 1993 and 1995, before and after a pro- 
gram implemented by Save the Children, USA (SC) and the Association for Social Advancement (ASA), a national credit scheme, was introduced in some selected villages in the thana. In Section II, the data are described and a brief description is given of the study area and the interventions. In Section III, the research strategy for measuring women's empowerment is presented. The method of evaluating the impact of credit programs is discussed in Section IV. The results of the analysis of the factors influencing the decision to join a credit or savings group are presented in Section V. In Section VI, the impact of credit and savings group membership on attitudes toward education and age at marriage of daughters is discussed. Sections VII and VIII present results concerning the impact of group membership on women's contraceptive use and fertility. Policy implications of the analysis are discussed in Section IX.

\section{DATA}

The data used for this study are drawn from a panel survey conducted by Save the Children, USA. The fieldwork for the first wave of the survey was carried out between October and December 1993 prior to the introduction of a new intervention in women's credit. SC has worked in some of the villages since the mid-1970s, when the focus of the agency's interventions was on overall development. Since the late 1980s, SC began experimenting with various women's programs. In 1994, the year following the baseline survey, SC planned to start a credit scheme with ASA in villages where they had not previously worked. The total sample covered by the baseline survey may be divided into three areas: an area where SC had non-credit programs since the mid-1970s (the "old" area), an area where SC was soon to begin new program interventions (the "new" area), and villages in the same thana that were similar to those in the new area but where no SC intervention was planned (the "control" area). The sample from the old area was drawn from a list maintained by SC of all individuals living in their 
program villages. The samples from the new and control areas were drawn from a sampling frame constructed by SC for the purposes of an earlier household survey conducted in the same areas. Essentially, the design follows the characteristics of cluster sampling. A total of 15 villages were surveyed, each village constituting a separate cluster. All ever-married women in these villages were considered as eligible respondents, and a total of 6,456 were successfully interviewed. The survey was repeated in 1995 with a sample of 5,696 women of whom 4,333 were reinterviews (see the appendix for a detailed discussion of the extent of attrition).

Women surveyed in 1993 may be divided into four groups for analytical purposes: (1) savings-group members in the old area; (2) poor women in the new area where SC had not yet introduced a credit program, but who would be eligible for membership when the savings groups were formed; (3) women in the same area who do not fulfill SC's eligibility criteria for group membership; and (4) the control group. Shortly after the first wave of the survey, SC established a savings program and a credit program in collaboration with ASA in the new area. By 1995, group 2, described above, were further divided into three subgroups: those who had chosen to join one of the newly formed SC savings groups, those who had joined a SC-ASA group, and nonmembers.

Naved (1997) describes the process by which these choices were made: Women who were interested in joining an organization but thought that the terms and conditions for receiving SC-ASA loans were too stringent were encouraged to form non-credit savings groups instead. SC-ASA requires an admission fee, and there are also individual and group expenses for meeting rooms. Weekly meetings are mandatory, and members are required to save as a group in a fund from which a member can make withdrawals only if she leaves the group. The group funds are managed by the credit officer who collects weekly savings and loan payments for deposit at a government bank. Because credit officers are re- 
quired to visit the villages in which they work, remote and inaccessible villages are excluded from the program.

SC savings groups include women who are not interested in receiving credit or are not eligible for credit because they have been judged to have a bad credit record. Some women preferred savings to credit groups simply because they thought the loan program was inappropriate for them. Relative to SC-ASA credit groups, SC groups are more autonomous and set their own rules with regard to frequency of meetings, savings contributions by members, size of group, and how group savings are managed. Some groups decided to lend group funds at above-market rates to generate profits for the group - a practice that is disallowed in an SC-ASA group.

The contrast between SC and SC-ASA groups represent two streams of thought in the field of micro-finance. Several new finance programs operate according to the idea that the savings function of credit groups is more valued and more important for the well-being of groups than is the credit that is provided (Wright, et al., 1997).

To test for the impact of savings and credit interventions, the study follows a quasi-experimental before-after design in which women in the new intervention area were surveyed both before and after the introduction of the program. At each round of the survey, information on a range of demographic and socioeconomic characteristics was collected. Complete birth histories were collected, including anthropometric measurements for each child. Current contraceptive use and ever use were also recorded. The key elements of the survey were sections on women's status and credit activity. A woman's status was measured by sets of questions designed to obtain information on, for example, her freedom to move outside her village and her role in household decisionmaking. To measure a woman's social independence, for instance, she was asked a series of questions about whether she was permitted to engage in a specified set of activities accom- 
panied or alone. The information on credit activity collected included details of the amount of credit she obtained, its source, and the purpose of the loan, and her membership in any group-based credit scheme.

\section{MEASUREMENT OF EMPOWERMENT}

The measures of women's empowerment were constructed to capture the multidimensional and multilocational nature of women's status described by Mason (1986). Four dimensions of status that are considered universally important were identified, and the authors attempted to specify them in contextually sensitive measures. In the SC panel study, a woman's empowerment was measured in four dimensions: mobility, her role in household decisionmaking, the treatment she receives from her husband, and her attitudes regarding her children's education and age at marriage. Mobility was measured by a series of questions on whether she is permitted to engage in the following activities alone: going to a movie; attending a woman's meeting; visiting a health center, subdistrict headquarters, or a nongovernmental organization office (NGO); shopping or selling; or visiting friends and relatives. Several of the responses to these questions were not considered in the analysis of program impact, however, because few women other than group members would have reason to attend a woman's meeting, or visit the subdistrict headquarters or an NGO office. A woman's authority within her household was measured by the extent of her role in making decisions about the following issues: purchase or sale of cattle or land; borrowing or lending money; house repairs; her own medical treatment; when to have children; and the number of children to have. In each case, the woman was asked whether she made these decisions alone or jointly with her husband or if they were made by her husband alone or by another household member. A woman's status within her marriage was measured not only by her role in decisionmaking but also in terms of the way in which she is treated by her husband. Respondents were asked whether 
they had ever experienced verbal or physical abuse from their husbands or received threats of divorce or another marriage. Finally, women were asked a series of hypothetical questions regarding their attitudes toward their sons' and daughters' education and age at marriage.

Tables 1, 2, and 3 present the distribution of responses for the selected empowerment indicators from the 1993 survey. The responses to questions on women's mobility reveal that few women are permitted to go outside their village to see a movie or to shop or sell, either accompanied or alone (see Table 1). However, the majority of women are able to visit a health center or meet friends and relatives if they are accompanied. The results shown in Table 2 reveal that the women surveyed have a low degree of autonomy in making household decisions. The majority of women play no role in decisions concerning financial matters or house repairs, and in 45 percent of cases, decisions about a woman's own medical treatment are made either by her husband alone or by another household member. Decisions about fertility are usually discussed jointly by husband and wife. The responses to questions on the treatment that a woman receives from her husband show that most women have suffered from verbal abuse, and almost one-third of women surveyed report being abused physically (see Table $3)$. Relatively few women have received threats of divorce or another marriage.

An overall measure of empowerment may be obtained by combining the responses given to the questions on women's status. Here, two scales are developed: one representing a woman's level of mobility and the other the extent of her role in household decisionmaking. These scales are constructed using latent trait analysis (Bartholomew, 1987). This technique is a special case of the more general latent structure models that have been applied predominantly in the social sciences to study the relationship between an observed set of indicators and some underlying concept that is difficult to measure directly. Examples of such unobservable concepts are intelligence, attitudes, or, in the present case, aspects 
Table 1 Percentage of currently married women who responded to questions about their personal mobility, by question, according to response, Bangladesh, 1993

\begin{tabular}{lccc}
\hline Question & $\begin{array}{c}\text { Yes, } \\
\text { alone }\end{array}$ & $\begin{array}{c}\text { Yes, } \\
\text { accompanied }\end{array}$ & No \\
\hline $\begin{array}{l}\text { Are you permitted to go outside the } \\
\text { village to }\end{array}$ & & & \\
$\quad$ See a movie & 0.5 & 5.2 & 94.3 \\
$\quad$ Go to a health center & 14.3 & 54.2 & 31.5 \\
$\quad$ Shop or sell & 1.4 & 2.5 & 96.1 \\
$\quad$ Visit friends or relatives & 26.1 & 71.0 & 2.9 \\
\cline { 2 - 3 } & Yes & No & \\
\cline { 2 - 3 } Did you talk to a man outside the village & & & \\
in the last six months? & 66.3 & 33.7 & \\
\hline
\end{tabular}

Table 2 Percentage of currently married women who responded to questions about their role in household decisionmaking, by question, according to response, Bangladesh, 1993

\begin{tabular}{lcccc}
\hline & & \multicolumn{3}{c}{$\begin{array}{c}\text { Other } \\
\text { (husband only } \\
\text { or other }\end{array}$} \\
Question & $\begin{array}{c}\text { Woman } \\
\text { only }\end{array}$ & $\begin{array}{c}\text { Woman } \\
\text { and } \\
\text { husband } \\
\text { household } \\
\text { member) }\end{array}$ & $(\mathbf{N})$ \\
\hline Who makes decisions with regard to & & & & \\
Borrowing or lending & 0.8 & 40.1 & 59.2 & $(3,614)$ \\
House repairs & 0.7 & 48.2 & 51.0 & $(3,615)$ \\
Medical treatment of the respondent & 2.9 & 52.3 & 44.8 & $(3,615)$ \\
When to have children & 2.1 & 83.6 & 14.3 & $(3,399)$ \\
Number of children & 1.1 & 84.3 & 14.6 & $(3,361)$ \\
\hline
\end{tabular}

Table 3 Percentage of currently married women who responded to questions about the treatment they received from their husbands, by question, according to response, Bangladesh, 1993

\begin{tabular}{lrr}
\hline Question & Yes & No \\
\hline Have you ever suffered any of the & & \\
following from your husband? & & \\
Verbal abuse & 85.0 & 15.0 \\
Physical abuse & 31.5 & 68.5 \\
Threats of divorce & 4.5 & 95.5 \\
Threats of his taking another wife & 4.1 & 95.9 \\
\hline
\end{tabular}


of women's empowerment. Latent trait analysis is a variation on factor analysis and is used when the observed indicators are categorical. As in factor analysis, the aim is to locate individuals on some underlying scale or latent variable. Although models may be specified with more than one latent variable or factor, the models used in this paper are restricted to a single latent variable that represents overall mobility or decisionmaking power, depending on the set of questions used in the model. From the fitted model, a score can be allocated to each individual that is the estimated conditional mean of the latent variable, given the woman's combination of responses on the observed set of indicators. The model assumes normality in the latent variable, and missing values can only be accommodated with the assumption that they are missing at random. The program TWOMISS (Albanese and Knott, 1992) was used to perform the latent trait analyses in this paper. This program was developed specifically for fitting latent trait models to binary data and has the added advantage of permitting missing values on any of the indicators.

Before carrying out the latent trait analysis, each empowerment indicator was coded as a $(0,1)$ binary variable where category 0 represents a low level of empowerment on that particular variable, and category 1 represents a relatively high level. For the mobility indicators, responses of "alone" or "accompanied" were combined, except for visits to friends or relatives where the responses "accompanied" and "no" were combined. From the decisionmaking questions, binary variables were constructed that indicate whether the woman had any say in decisionmaking, that is, whether she could make decisions either on her own or jointly with her husband. In order to test whether the sets of questions on mobility and decisionmaking do in fact capture two distinct dimensions of empowerment, the correlations between each pair of indicators used to construct the scales were calculated. Because the indicators are categorical, an appropriate measure of correlation is the odds or cross-product ratio. Table 4 presents the odds ratios 


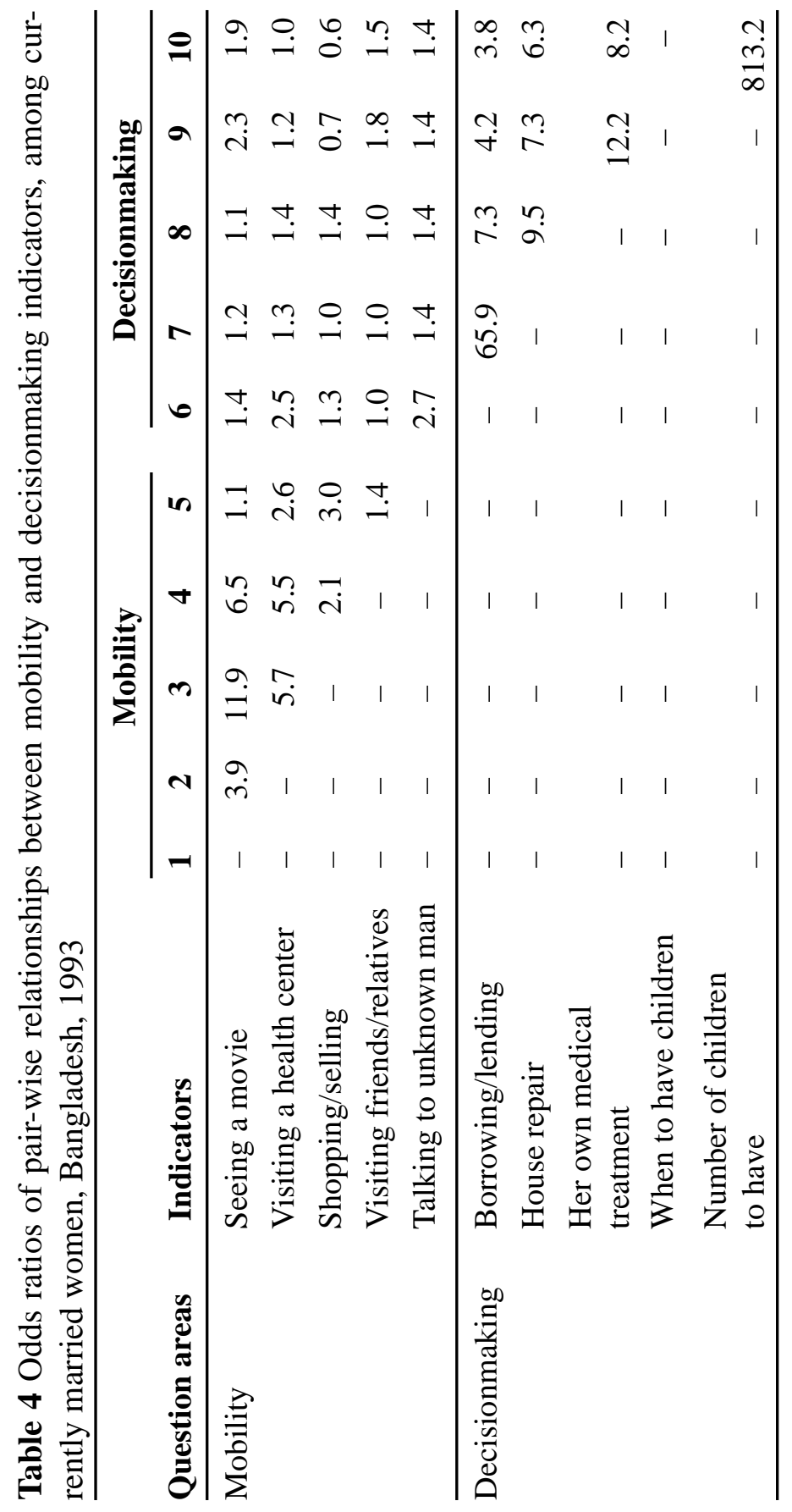


for variables from each of the two sets of questions. Although the correlations between pairs of indicators within each set of questions are, in general, relatively high (indicated by large odds ratios), correlations between pairs of variables from different sets tend to be small (indicated by odds ratios close to 1). Thus constructing two separate scales, one each for mobility and decisionmaking would seem more useful than combining both sets of indicators to form a single scale.

The latent trait analysis yields two scales. The scale for mobility ranges from -1.14 (representing women who responded negatively on all five indicators) to 2.14 (representing a set of positive responses). Similarly, a scale for decisionmaking was constructed that ranges from -1.57 to 1.05 , where negative values correspond to women with below-average decisionmaking power in their households.

\section{Methods for Evaluating Program Impact}

One factor that must be considered in the evaluation of the impact of any program in which participation is voluntary is self-selection bias. Women choose whether they wish to join a credit program and the program likely attracts women who are more independent than others or who are more likely to use or start to use contraceptives. Thus, high levels of empowerment and contraceptive use among group members cannot be attributed to the program alone without controlling for the likelihood of selection bias. Clearly, analyses that do not allow for self-selection tend to lead to estimates that overstate program impact. Although several studies have attempted to evaluate the effects of credit-program participation on reproductive and other behaviors, relatively few have addressed the issue of self-selection satisfactorily.

In order to establish causal relationships between savings- group membership and women's empowerment and fertility behavior, program effects must be disentangled from selectivity effects. Two-stage models are often used to control 
for self-selection bias (Maddala, 1983). Pitt et al. (1995) use a two-stage approach to evaluate the effect of three group-based credit programs on current contraceptive use and fertility in Bangladesh and found that apparently strong program effects were diluted considerably after adjusting for selectivity. If the only data available for program evaluation are cross-sectional, a two-stage approach is appropriate in order to unravel program and selectivity effects. This approach should be viewed with some skepticism: It requires a variable that affects group membership, but given membership, does not further affect the demographic outcome of interest. Such restrictions are hard to find, and fortunately, longitudinal data render these restrictions unnecessary.

The quasi-experimental panel design of the present study allows a control for selection that uses prior characteristics on contraceptive-use status and other background variables. The survey provides information on a respondent's level of empowerment and contraceptive behavior both before and after the formation of groups in SC's new intervention area. Thus, preprogram measures of empowerment and contraceptive use can be incorporated in the analysis of factors influencing postprogram outcomes to control for the self-selection of women with higher status and a greater propensity to use contraceptives. Schuler and Hashemi (1994) and Amin et al. (1995) allow for selectivity in this way. Both studies attempt to control for the possibility of selection bias in evaluations of the impact of Grameen Bank and BRAC credit organizations on women's current contraceptive use by inclusion in their analyses of an indicator of respondents' contraceptive behavior prior to joining the program. In another study of Grameen Bank, Rahman and DaVanzo (1997) collected retrospective data on the timing both of participation in a credit program and of contraceptive adoption. Therefore, they were able to determine whether a woman commenced using a contraceptive method before or after she joined a credit program and to evaluate the impact of the duration of membership on contraceptive adoption in a longitudinal analysis. 
The before-after design of the present study provides a large amount of preintervention information, including previous contraceptive use and indicators of empowerment. One aim of this paper is to identify the factors that influence the decision to join a credit or savings group. Program effects are estimated by comparing 1995 outcomes of empowerment and fertility among credit-group members in the new area both with nonmembers in the same villages and women in the nonprogram control villages, after controlling for characteristics found to be associated with the propensity to participate in the program.

\section{CharaCteristics OF SAVings-group MEMbERS}

The quasi-experimental panel design of the study provides a rare opportunity to identify the characteristics of women who choose to participate in credit programs. Knowledge of the type of women who join credit or savings groups will also be used to determine a set of suitable control variables to allow for selection bias in the following analyses of program impact on empowerment and contraceptive use.

The subsample of women resident in the new intervention area who were eligible for credit- or savings-group membership is considered here. The analysis is further restricted to women who were currently married at the time of the 1993 survey to obtain a sample size of 1,495 women. Thirty-one percent of women became members of a SC or SC-ASA group between 1993 and 1995, of whom 74 percent joined groups organized by SC-ASA.

Multinomial logistic regression is used to identify the characteristics associated with program participation. Membership status is categorized as follows: SC member, SC-ASA member or nonmember. A range of sociodemographic variables is considered, including the woman's age, number of children, education, employment, contraceptive use, and measures of her empowerment. All covariates are taken from the 1993 survey before the savings groups were formed. 
Table 5 displays the results from the multinomial regression analysis of savings-group membership. To illustrate the magnitude of the effects of the statistically significant covariates, the estimated coefficients have been used to calculate probabilities of SC and SC-ASA participation (see Table 6). These probabilities have been calculated for each variable in turn while holding all others constant at their sample mean. The analysis reveals that although some schooling has a significant and positive impact on a woman's likelihood of joining an SCASA group, the effect on the probability of SC membership is negative. The

Table 5 Multinomial logit regression analysis of membership of SC and SCASA groups among target women in the new intervention area, Bangladesh, 19931995

\begin{tabular}{|c|c|c|c|c|}
\hline \multirow[b]{2}{*}{ Variable $^{a}$} & \multicolumn{2}{|c|}{$\begin{array}{l}\text { SC group } \\
\text { vs. nonmember }\end{array}$} & \multicolumn{2}{|c|}{$\begin{array}{l}\text { SC-ASA group } \\
\text { vs. nonmember }\end{array}$} \\
\hline & Estimate & (SE) & Estimate & (SE) \\
\hline Constant & -1.69 & $(0.24)$ & -1.72 & $(0.19)$ \\
\hline Woman ever attended school & $-0.48 *$ & $(0.28)$ & $0.47 * * *$ & $(0.15)$ \\
\hline Husband ever attended school & 0.04 & $(0.23)$ & $0.58 * * *$ & $(0.15)$ \\
\hline $\begin{array}{l}\text { Woman worked for cash or kind } \\
\text { during last year }\end{array}$ & 0.22 & $(0.36)$ & $0.50 * *$ & $(0.21)$ \\
\hline $\begin{array}{l}\text { Woman suffered verbal abuse } \\
\text { from husband }\end{array}$ & $-0.94 * * *$ & $(0.24)$ & -0.28 & $(0.18)$ \\
\hline $\begin{array}{l}\text { Woman suffered threats of husband's } \\
\text { taking another wife }\end{array}$ & $0.78 *$ & $(0.41)$ & $0.55^{*}$ & $(0.29)$ \\
\hline Score of woman's mobility ${ }^{b}$ & 0.05 & $(0.16)$ & $0.44 * * *$ & $(0.11)$ \\
\hline $\begin{array}{l}\text { Score of woman's household } \\
\text { decisionmaking }\end{array}$ & -0.1 & $(0.13)$ & 0.07 & $(0.09)$ \\
\hline $\begin{array}{l}\text { Woman was current user of } \\
\text { contraceptives in } 1993\end{array}$ & $0.66 * *$ & $(0.31)$ & $0.69 * * *$ & $(0.20)$ \\
\hline
\end{tabular}

* Significant at $\mathrm{p} \leq 0.10 ; * * \mathrm{p} \leq 0.05 ; * * * \mathrm{p} \leq 0.001 .{ }^{\mathrm{a}}$ All variables are taken from the 1993 survey. ${ }^{b}$ Mobility and household decisionmaking scores are constructed using latent trait analysis. See text for details. 
Table 6 Estimated rates (percents) of credit-program participation among target women in the new intervention area, by selected variables, Bangladesh, 1993-95

\begin{tabular}{lccc} 
Variable & $\begin{array}{c}\text { SC } \\
\text { member }\end{array}$ & $\begin{array}{c}\text { SC-ASA } \\
\text { member }\end{array}$ & $\begin{array}{c}\text { Non- } \\
\text { membe }\end{array}$ \\
\hline $\begin{array}{l}\text { Woman ever attended school } \\
\quad \text { Yes }\end{array}$ & 4.4 & 22.9 & 72.3 \\
$\quad$ No & 7.5 & 15.2 & 77.3 \\
Husband ever attended school & & & \\
$\quad$ Yes & 6.2 & 22.9 & 70.9 \\
No & 6.6 & 14.3 & 79.1
\end{tabular}

Woman worked for cash or kind during last year

Yes

7.1

24.2

68.7

No

6.4

16.5

77.1

Woman suffered verbal abuse from husband

Yes

5.6

16.6

77.8

No

12.6

19.2

68.1

Woman suffered threats of husband's taking another wife
Yes
11.4
24.3
64.3
No
6.3
16.8
77.0
Score of woman's mobility
Very low $(-1.14)$
6.6
11.5
81.9
Average (0)
6.5
17.1
76.4
Very high (2.14)
5.6
35.3
59.1

Woman was current user of contraceptives in 1993
Yes
9.8
26.4
63.8
No
6.1
16.1
77.7

Note: Rates are calculated from the multinomial regression model in Table 5. Probabilities are estimated for each variable in turn, whereas the values of all other variables in the model are held constant at sample means. 
woman's paid employment, husband's education, and the woman's mobility also have a significant positive impact on SC-ASA membership, but nonsignificant effects on SC membership. These results may be interpreted in two ways. They may indicate that SC-ASA attracts women who are relatively empowered, at least in terms of their education, mobility, and employment status. An alternative explanation is that SC-ASA is more selective in the type of women they recruit into their program. Women who were using contraceptives at the time of the 1993 survey are more likely to join either SC or SC-ASA groups than are nonusers. This result supports the theory that savings groups attract women who have a propensity to use contraceptives and highlights the need to control for the premembership level of contraceptive use in order to evaluate properly the contribution of the credit program with regard to any change in contraceptive behavior.

Two variables relating to a woman's treatment by her husband are found to have significant effects on credit-group participation. Women who have suffered verbal abuse are less likely to join an SC group than are those who have not, but threats that her husband might make another marriage increase a woman's propensity to join either program. Verbal abuse may be considered a milder form of mistreatment, and women who suffer from such abuse may prefer to maintain the status quo rather than invoke their husband's anger by becoming involved in a credit program. A husbands' threats of making another marriage may be considered as an indicator of more serious ill-treatment. A woman who experiences this type of abuse is likely to feel insecure in her marriage and may seek to become more financially independent through membership in a credit organization. Mahmud and Huda (1997) found that women who stated that they had bad relationships with their husbands had an greater probability than did others of participating in BRAC's Rural Development Program in Matlab.

Naved (1997) provides further evidence of selectivity in a qualitative study of the SC-ASA program. She describes how women judged to be poor credit 
risks are not accepted into the program, which rejection leads to the exclusion of the poorest women. These women may also exclude themselves because they find the strict conditions of SC-ASA credit onerous. One condition of membership is regular attendance at meetings, which is problematic for many women, particularly young married women whose mobility is restricted. As a result, these women may choose not to join a SC-ASA group or may be excluded by ASA staff in the group-formation process.

\section{THE IMPACT OF MEMBERSHIP ON ATTITUDES}

Women's attitudes toward female education and age at marriage are examined here as measures of empowerment because relatively little change was found in the other empowerment indicators, mobility and decisionmaking, over the observation period. This finding is not surprising because in the new intervention area, the maximum duration of exposure to the credit program is only two years. Although a change in attitudes might reasonably be expected within a two-year time interval, discernible changes in behavior in such a short period of time seem less plausible. Another potential problem when mobility and decisionmaking indicators are considered is that even if no real change has occurred in a woman's empowerment with respect to these dimensions, her perceptions of what she is permitted to do and of her role within the household may have altered. Furthermore, participation in credit programs may heighten a woman's consciousness of her lack of freedom and autonomy, and this awareness may influence the responses she gives to these particular questions. In such cases, distinguishing between real changes over time in mobility and decisionmaking and changes in perceptions are difficult.

The analysis sample consists of all women who were currently married at the time of the 1993 survey, a total of 3,611 respondents. As described above, six categories of women may be defined according to their area of residence, eligi- 
bility for program participation, and membership status. However, since SCASA did not target all villages in the new area, a further distinction is made here between areas where SC-ASA programs were available and villages that were excluded. This distinction produces eight comparison groups. Table 7 presents the mean number of years of education and age at marriage that women in each of these eight categories reported as their ideal for their daughters in 1993 and 1995. Also shown is the percentage increase in the reports over the two-year period. Although little change is seen in attitudes among women in the old and control areas, much larger shifts are apparent in the new intervention area. The main comparisons of interest are between nonmembers and SC members in nonASA villages (rows 4 and 5 in Table 7), and among SC members, SC-ASA members and nonmembers in ASA villages. The largest increase in reported ideal years of female education is observed among SC-ASA group members, but interestingly, the level of increase among SC members is lower than that observed

Table 7 Respondents' reports of their mean ideal years of female education and age at marriage for their daughters, by area of residence and savings-group membership status, Bangladesh, 1993-95

\begin{tabular}{|c|c|c|c|c|c|c|c|}
\hline \multirow[b]{2}{*}{ Membership status } & \multicolumn{3}{|c|}{$\begin{array}{l}\text { Mean ideal number } \\
\text { years of female } \\
\text { education }\end{array}$} & \multicolumn{3}{|c|}{$\begin{array}{c}\text { Mean ideal } \\
\text { daughter's age } \\
\text { at marriage }\end{array}$} & \multirow[b]{2}{*}{$\mathrm{e}^{\mathrm{a}} \quad(\mathbf{N})$} \\
\hline & 1993 & 1995 & $\begin{array}{l}\text { Percent } \\
\text { increase }^{\mathrm{a}}\end{array}$ & 1993 & 1995 & $\begin{array}{l}\text { Percent } \\
\text { increase }^{\mathrm{a}}\end{array}$ & \\
\hline Old area/ member & 7.8 & 7.9 & 1.3 & 17.6 & 18.0 & 2.3 & $(457)$ \\
\hline Control area/ target & 7.2 & 7.0 & -2.8 & 17.3 & 17.8 & 2.9 & $(740)$ \\
\hline New area/ nontarget & 8.5 & 9.2 & 8.2 & 17.9 & 18.2 & 1.7 & (919) \\
\hline New area/ nonmember & 6.8 & 7.8 & 14.7 & 16.8 & 17.4 & 3.6 & $(1,031)$ \\
\hline New area/ SC member & 7.3 & 7.7 & 5.5 & 17.4 & 17.2 & -1.1 & $(121)$ \\
\hline New area/ SC-ASA member & - 7.9 & 10.0 & 26.6 & 17.4 & 18.7 & 7.5 & $(342)$ \\
\hline
\end{tabular}

${ }^{a}$ Calculated as (1995 mean-1993 mean)/(1993 mean) x 100\%. 
among nonmembers in both ASA and non-ASA target areas. Similar but less pronounced patterns of change are observed in attitudes toward the ideal age of female marriage, and again the increase is highest among SC-ASA members in the new area.

The apparent effects of SC-ASA groups on changes in attitudes toward female education and daughters' age at marriage are due to selection bias. As the analysis of the factors influencing program participation reveals, women who have attended school and those with a relatively high level of mobility have an increased likelihood of joining a credit group, and these women will probably also have less traditional attitudes toward female education and age at marriage. Table 7 shows that the preprogram mean ideal years of education and age at marriage are higher for members than for nonmembers in both ASA and nonASA villages. Therefore, in order to evaluate the impact of the credit program on women's attitudes toward education and age at marriage, a multivariate analysis must control for their level of independence, in terms of their mobility and attitudes, before the introduction of the program.

The results from linear regression analyses of respondents' attitudes toward the ideal level of women's education and age at marriage in 1995 are presented in Tables 8 and 9, respectively. In the analysis of attitudes toward female education, the respondent's own level of education is the major determinant of her aspirations for a daughter. Her level of mobility in 1993 is also positively associated with her reported ideal years of education. Poorer households, that is, those that are landless or who have an outstanding loan, place less value on female education than do households that are more secure financially.

The main focus of the analysis is the comparison between members and nonmembers in non-ASA villages, and among SC and SC-ASA members and nonmembers in villages where ASA operates. Even after controlling for premembership measures of empowerment and other characteristics, a signifi- 
Table 8 Linear regression of respondents' reported attitudes toward ideal years of female education, Bangladesh, 1995

\begin{tabular}{|c|c|c|}
\hline Variable $^{\mathrm{a}}$ & Estimate & (SE) \\
\hline Constant & 6.17 & $(0.17)$ \\
\hline Reported ideal years of female education in 1993 & $0.21 * * *$ & $(0.02)$ \\
\hline Woman ever attended school & $1.36 * * *$ & $(0.12)$ \\
\hline Mobility score ${ }^{b}$ & $0.17 * *$ & $(0.08)$ \\
\hline Household decisionmaking score & 0.02 & $(0.06)$ \\
\hline Household has no land & $-0.43 * * *$ & $(0.12)$ \\
\hline Household has no outstanding loan ${ }^{\mathrm{c}}$ & $0.35^{* *}$ & $(0.12)$ \\
\hline \multicolumn{3}{|l|}{ Area and savings-group membership ${ }^{d}$} \\
\hline Old area/ member & 0.03 & $(0.18)$ \\
\hline Control area/ target & $-0.97 * * *$ & $(0.15)$ \\
\hline New area/ nontarget & $0.62 * * *$ & $(0.16)$ \\
\hline New area/ SC member & -0.14 & $(0.30)$ \\
\hline New area/ SC-ASA member for 12 months or less & $1.01 * * *$ & $(0.29)$ \\
\hline New area/ SC-ASA member for more than 12 months & $2.19 * * *$ & $(0.28)$ \\
\hline
\end{tabular}

* Significant at $\mathrm{p} \leq 0.10 ; * * \mathrm{p} \leq 0.05 ; * * * \mathrm{p} \leq 0.001 .{ }^{\text {a }}$ All variables are taken from the 1993 survey. ${ }^{\mathrm{b}}$ Mobility and household decisionmaking scores are constructed using latent trait analysis. See text for details. ${ }^{\mathrm{c}}$ This is a preintervention measure and does not refer to credit obtained from any savings group. ${ }^{\mathrm{d}}$ The reference category is new area/nonmember.

cant difference remains in attitudes toward ideal years of female education among women who joined SC-ASA savings groups and nonmembers in ASA areas. However, this effect is not statistically significant until after one year of membership. The ideal number of years of female education according to women who have been SC-ASA group members for more than a year is estimated to be on average one and a half years higher than that reported by their counterparts who chose not to participate in the credit program. No evidence is found of a difference between SC members and nonmembers in either ASA or non-ASA villages. The comparison between SC-ASA group members and nonmembers on ideal 
Table 9 Linear regression of respondents' reported attitudes toward ideal age of female marriage, Bangladesh, 1995

\begin{tabular}{lcc}
\hline Variable $^{\mathrm{a}}$ & Estimate & $(\mathbf{S E})$ \\
\hline Constant & 14.78 & $(0.39)$ \\
Reported ideal age of female marriage in 1993 & $0.11^{* * *}$ & $(0.02)$ \\
Woman ever attended school & $1.01^{* * *}$ & $(0.11)$ \\
Mobility score & -0.01 & $(0.07)$ \\
Household decisionmaking score & 0.08 & $(0.05)$ \\
Age at first marriage & $0.04^{* *}$ & $(0.02)$ \\
Household has no land & -0.06 & $(0.10)$ \\
Household has no outstanding loan & 0.05 & $(0.10)$ \\
Area and savings-group membership & & \\
$\quad$ Old area/ member & & $(0.16)$ \\
Control area/ target & $0.57 * * *$ & $(0.13)$ \\
New area/ nontarget & $0.27 * *$ & $(0.13)$ \\
New area/ SC member & $0.50^{* * *}$ & $(0.26)$ \\
New area/ SC-ASA member for 12 months or less & $0.67 * * *$ & $(0.24)$ \\
New area/ SC-ASA member for more than 12 months & $1.59^{* * * *}$ & $(0.22)$
\end{tabular}

* Significant at $\mathrm{p} \leq 0.10 ; * * \mathrm{p} \leq 0.05 ; * * * \mathrm{p} \leq 0.001 .{ }^{\text {a }}$ All variables are taken from the 1993 survey. ${ }^{\mathrm{b}}$ Mobility and household decisionmaking scores constructed using latent trait analysis. See text for details. ${ }^{c}$ Reference category is new area/nonmember.

age at marriage also suggests a positive effect of SC-ASA membership (see Table 9), and this effect strengthens with duration of membership.

Another comparison of interest is between all women in the new intervention area who were eligible to participate in the SC and SC-ASA programs (the target group) and those in nonintervention villages who fulfill the basic loaneligibility criteria (the control group). Several studies have commented on the possibility of diffusion effects where a credit program influences the behavior not only of members but also of nonmembers living in program villages (Rahman 
and DaVanzo, 1997; Schuler and Hashemi, 1994; Schuler et al., 1997). For example, Schuler and Hashemi (1994) found a positive impact of Grameen Bank participation on women's empowerment, but also found that the level of independence was significantly higher among nonmembers in Grameen Bank villages than among women in comparison nonprogram villages. A similar effect is observed here on aspirations regarding female education: Respondents in the control area reported ideal levels of female education that were statistically significantly lower than those reported by nonmembers in ASA villages in the new area, with an estimated mean difference of 1.66 years. This finding would suggest that the attitudes of all women who are targeted by SC-ASA, both members and nonmembers, are influenced by the credit program. In this case, a more appropriate measure of the effect of credit-group participation may be obtained from a comparison of credit-group members and women in the control area. The attitudes of women in non-ASA villages toward female education in the new area are similar to those of the control-group women, a finding suggesting that the credit component offered by ASA may influence change in these attitudes.

In order to assess program impact on more focused measures of women's attitudes toward gender equity in levels of education and age at marriage, the above analyses were repeated using the differences between the reported attitudes toward ideal years of education and age at marriage for sons and daughters as outcome variables (results not shown). These analyses show that although SC-ASA group members have higher aspirations than others for levels of female education and later age at marriage, they are also more likely to report high aspirations for their sons. Their stated aspirations do not reflect any diminution of gender inequity. Amin and Pebley (1994) found similar changes in rising aspirations with regard to female education and delayed marriage but no change in the implied differentials in education and age at marriage for girls and boys related to credit-program participation. 


\section{THE IMPACT OF PROGRAM MEMBERSHIP ON CONTRACEPTIVE USE}

In the analysis of program impact on contraceptive use, all women who were currently married at both surveys and aged between 15 and 45 in 1995 are considered. The proportions of currently married women using a modern method of contraception in 1993 and 1995 by area of residence and credit-program participation are shown in Table 10. In 1993, the highest level of modern contraceptive use was among group members in the old SC intervention area. In all categories except for the control area, a considerable increase has occurred in contraceptive use, and by 1995, use was highest among SC-ASA members in the new intervention area. However, those who chose to join either SC or SC-ASA groups reported higher preintervention levels of contraceptive use than did nonmembers in the same area. Table 11 presents the results from a logistic regression analysis of the probability of respondents' using modern contraceptives in 1995. In order to evaluate the contribution of the SC and SC-ASA credit programs on

Table 10 Percentage of women surveyed aged 15-49 who reported current use of modern contraceptives, by area of residence and savings-group membership status, Bangladesh, 1993-95

\begin{tabular}{llcr}
\hline & \multicolumn{2}{c}{$\begin{array}{c}\text { Use modern } \\
\text { contraceptives }\end{array}$} & \\
\cline { 2 - 3 } Area/ savings-group & $\mathbf{1 9 9 3}$ & $\mathbf{1 9 9 5}$ & (N) \\
\hline Old area/ member & 36.2 & 46.3 & $(378)$ \\
Control area/ target & 13.7 & 14.7 & $(621)$ \\
New area/ nontarget & 12.1 & 37.2 & $(702)$ \\
New area/ nonmember & 9.2 & 34.6 & $(872)$ \\
New area/ SC member & 14.3 & 37.8 & $(98)$ \\
New area/ SC-ASA member & 20.1 & 47.2 & $(284)$ \\
\hline
\end{tabular}


Table 11 Logistic regression analysis of current use of modern contraceptives at time of 1995 survey, among women age 15-45 in 1995

\begin{tabular}{lcc}
\hline Variable $^{\mathrm{a}}$ & Estimate & (SE) \\
\hline Constant & -1.09 & $(0.22)$ \\
Woman ever attended school & $0.29^{* * *}$ & $(0.10)$ \\
Husband ever attended school & $0.29^{* * *}$ & $(0.10)$ \\
Worked for cash or kind during last year & -0.03 & $(0.16)$ \\
Current age (years) & -0.01 & $(0.01)$ \\
Number of living children & $0.10^{* * *}$ & $(0.03)$ \\
Mobility score & -0.03 & $(0.07)$ \\
Household decisionmaking score & $0.18^{* * * *}$ & $(0.05)$ \\
Area and savings-group membership & & \\
$\quad$ Old area/ member & & $(0.14)$ \\
Control area/ target & 0.20 & $(0.14)$ \\
New area/ nontarget & $-1.38^{* * *}$ & $(0.12)$ \\
New area/ SC member & -0.04 & $(0.12)$ \\
$\quad$ New area /SC-ASA member for 12 months or less & -0.04 & $(0.21)$ \\
$\quad$ New area/ SC-ASA member for more than 12 months & 0.15 & $(0.21)$ \\
Used contraceptives before 1993 & $1.40^{* * * *}$ & $(0.10)$
\end{tabular}

*Significant at $\mathrm{p} \leq 0.10 ; * * \mathrm{p} \leq 0.05 ; * * * \mathrm{p} \leq 0.001$. ${ }^{\text {a }}$ All variables are taken from the 1993 survey. ${ }^{\mathrm{b}}$ Mobility and household decisionmaking scores are constructed using latent trait analysis. See text for details. ${ }^{c}$ Reference category is new area/nonmember.

the increase in contraceptive use, a number of covariates are considered to allow for self-selection bias and other factors commonly associated with the propensity to practice contraception. In particular, preintervention measures of empowerment are included, as well as an indicator of whether the woman had ever used contraceptives before the start of the program in 1993. The results show that even after controlling for prior use, SC-ASA members are more likely to use modern contraceptives in 1995 than are nonmembers in the same villages. Evidence is clear that duration of membership is important, because no significant difference 
is apparent until women have been involved in the credit scheme for at least a year. Compared with that for nonmembers, the odds of using a modern method is 1.8 times higher for women who have been SC-ASA members for a year or more.

In both ASA villages and villages that do not offer a SC-ASA program, no significant impact of membership in a SC savings group is found on use of contraceptives. Positive effects of membership duration on current contraceptive use have been found by other researchers. For example, Schuler et al. (1997) and Rahman and DaVanzo (1997) both found that the propensity to practice contraception increases with duration of Grameen Bank membership. Another study, Amin et al. (1995), found a positive impact of program participation, but did not test for duration effects.

A comparison of nonmembers in the new area and women in the control area reveals that those in nonprogram villages are considerably less likely to use contraceptives. This finding is consistent with the difference in attitudes toward female education observed earlier between these same two groups of women and may again suggest a diffusion effect. Schuler et al. (1997) found a similar result in their study of contraceptive use that they attribute to diffusion factors or possibly to selection effects due to nonrandom program placement. In the present case, because SC also implemented a child-survival program in the new area at the same time that incorporated a family planning motivation component, disentangling contagion effects of the credit program from the direct health intervention effects is not possible.

\section{THE IMPACT OF PROGRAM MEMBERSHIP ON RECENT FERTILITY}

In this analysis, the impact of program participation on fertility during the intersurvey period 1993 to 1995 is assessed in order to determine whether higher contraceptive use among SC-ASA group members led to a change in their fertil- 
ity. Recent fertility is considered rather than a cumulative measure of fertility such as the number of children ever born. Cumulative measures may reflect behavior before the credit program was introduced, whereas fertility between 1993 and 1995 reflects only behavior that might have been influenced by program participation. The evidence from previous studies of the effects of credit programs on recent fertility is inconclusive. Amin et al. (1995) examined fertility during a five-year window and found a negative program effect. Rahman and DaVanzo (1995) found that membership of Grameen Bank groups and groups organized by other NGOs had a strong negative impact on parity progression. However, after controlling for self-selection bias, Pitt et al. (1995) found that although male participation in Bangladesh Rural Development Board and Grameen Bank groups reduced the probability of a birth in a four-year period, female participation was associated with higher fertility.

Event-history-analysis techniques are used to model the probability of a conception between October 1993 and October 1995. This approach is appropriate for two main reasons. First, many women did not conceive during the observation period and an event-history model allows these censored cases to be retained in the analysis. Second, the covariate of major interest, program participation, is time-varying; an event-history analysis allows us to examine the link between the timing and duration of membership and the timing of a conception (assumed to be the date of birth of a child minus nine months or, for women pregnant at the 1995 survey, the interview date minus four months). A discretetime model is used that involves splitting the observation period into one-month intervals. Thus, the estimated coefficients presented in Table 12 show the effects of covariates on the probability or hazard of a conception in a one-month interval, given that a conception has not already occurred. Women who were older than 40 at the time of the 1993 survey were excluded from this part of the analysis as were women who had been sterilized before October 1993. 
Table 12 Event-history model of the probability of conceiving a child between October 1993 and October 1995 among women aged 15-40 in 1993, Bangladesh

Variable

Constant
Duration since last birth (months) $)^{\mathrm{a}, \mathrm{b}}$

$12-23$

24-35

$>36$

Number of living children in 1993

Woman ever attended school

Mobility score in 1993

Decisionmaking score in 1993

Area and savings-group membership ${ }^{c}$

Old area/ member

Control area/ target

New area/ nontarget

New area/ SC member for 12 months or less ${ }^{\mathrm{a}}$

New area/ SC member for more than 12 months $^{\mathrm{a}}$

New area/ SC-ASA member for 12 months or less ${ }^{\text {a }}$

New area/ SC-ASA member for more than 12 months $^{\mathrm{a}}$
Estimate

$-4.18$

$$
\begin{aligned}
& 1.02 * * * \\
& 1.59 * * * \\
& 1.16 * * * \\
& -0.15 * * * \\
& -0.16 * * \\
& -0.02 \\
& -0.06
\end{aligned}
$$

* Significant at $\mathrm{p} \leq 0.10 ; * * \mathrm{p} \leq 0.05 ; * * * \mathrm{p} \leq 0.001$. ${ }^{\text {DDuration since last birth and savings- }}$

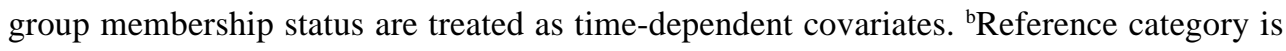
less than 12 months. ${ }^{~}$ Reference category is new area/nonmember.

The results from the event-history model show no statistically significant effect of either SC or SC-ASA group membership on the probability of conceiving between 1993 and 1995, regardless of the duration of membership. However, some evidence is seen that conception rates are lower among women in the old area than for any other area-membership-status category.

Several possible explanations may be given for the apparently contradictory finding that although program participation is associated with increased use of modern contraceptives, it does not affect fertility. One explanation is that the 
program might affect birth spacing rather than limiting behavior through increased contraceptive use. Another interpretation of these results could be that the program does influence fertility desires and that savings-group members are practicing contraception to achieve their goals, but that they are not using methods efficiently. High failure rates among program participators may counterbalance any program effect on conception rates. Unfortunately, testing this particular hypothesis is not possible because information on contraceptive failures was not collected.

In order to test the hypothesis that program participation affects birth spacing rather than limiting, the interaction between savings-group membership and the duration of time since the last birth was considered (results not shown). If group members were more likely to space their births than were nonmembers, we would expect the hazard of conception at short durations to be low for members relative to that for nonmembers. Little evidence was found, however, to suggest that program participation is associated with longer birth intervals.

A preference for large family size remains in the areas under study. In 1993, the mean ideal family size was 3.7 children, compared with the national mean of 2.5 children (Mitra et al., 1994). Virtually no change is seen in the twoyear period following the 1993 survey; in 1995, the mean ideal family size was 3.6 children. A slightly larger decline is seen among SC-ASA members in the new area (from 3.6 children in 1993 to 3.2 in 1995) and among members in the old area (from 3.8 children to 3.5 ). In an attempt to determine whether membership in a savings scheme influences fertility desires, the responses to a question on whether the respondent would like another child were analysed, controlling for fertility desires prior to membership and other important factors. A logistic regression analysis was performed in which the dependent variable was coded as 1 if in 1995 the woman reported that she wanted another child and 0 if she did not. The response given in 1993 to this question was included as a covariate to control for differences in fertility desires at the baseline. Other covariates considered were whether she had a live birth in 1993-95, the number of her living 
Table 13 Logistic regression analysis of fertility desires at time of 1995 survey among women aged 15-40 in 1993, Bangladesh

\begin{tabular}{lcc}
\hline Variable & Estimate & (SE) \\
\hline Constant & 2.02 & $(0.15)$ \\
Fertility desires (1993) /had live birth in 1993-95 & & \\
$\quad$ Wanted child /did not have birth & $0.45^{* * *}$ & $(0.13)$ \\
$\quad$ Did not want child /had birth & $-1.21^{* * *}$ & $(0.20)$ \\
$\quad$ Did not want child /did not have birth & $-1.02 * * *$ & $(0.15)$ \\
Number of living children in 1993 & $-0.50^{* * *}$ & $(0.03)$ \\
Husband ever attended school & $-0.28 * * *$ & $(0.11)$ \\
Mobility score in 1993 & 0.06 & $(0.08)$ \\
Household decisionmaking score in 1993 & $-0.24 * * *$ & $(0.06)$ \\
Area and savings-group membership & & \\
Old area/ member & & $(0.17)$ \\
Control area/ target & $-0.47 * * *$ & $(0.15)$ \\
New area/ nontarget & $-0.31 * *$ & $(0.14)$ \\
New area/ SC member & 0.05 & $(0.33)$ \\
New area/ SC-ASA member & 0.39 & $(0.19)$
\end{tabular}

*Significant at $\mathrm{p} \leq 0.10 ; * * \mathrm{p} \leq 0.05 ; * * * \mathrm{p} \leq 0.001$.

Note: Fertility desires are measured by whether woman reported that she wanted another child at the time of 1995 survey. The dependent variable is coded as follows: $1=$ wanted another child; $0=$ did not want another child (the reference category). ${ }^{a}$ Reference category

children in 1993, her education and that of her husband, and her mobility and decisionmaking scores from 1993. The results show that statistically, neither SC or SC-ASA membership has a significant impact on fertility desires (see Table 13). Thus, these results appear to be consistent with those from the analysis of recent fertility: savings- or credit-group membership has no significant effect on fertility desires and, therefore, no impact on conception rates.

Although the analyses of fertility desires and conception rates in the 199395 period show no evidence of a program effect among women in the new area, at the time of the 1995 survey, the maximum duration of program participation in 
this area was only two years. Fertility effects likely will become more evident at longer durations of membership. Indeed, the results of this study show that savings-group members in the old area, where the program was established during the late 1980s, were the least likely to conceive between 1993 and 1995 (as shown in Table 12) and the least likely to report in 1995 that they would like to have another child (see Table 13). However, a dramatic increase in contraceptive use occurred during the first two years of credit program introduction in the new areas, compared with almost no change in the control area (as shown in Table 10). The additional increase among women who had been members of a SCASA group for more than a year (see Table 11) suggests that contraception is one of the first areas of behavioral change to be associated with a credit program.

\section{DISCUSSION}

In this analysis of the impact of a typical women's credit program we find considerable evidence of selectivity of members. Women who join are more likely to be educated, to be married to better-educated men, to have worked for cash, to have received threats from their husbands that they might take another wife, and to have indicated that they had relatively high freedom of movement before they joined credit groups, relative to eligible women who did not join. The indicators suggest that credit-group members are more likely to be familiar with or in need of extrafamilial support. Women who join savings rather than credit groups, on the other hand, are less likely to be familiar with or in need of extrafamilial support by the same criteria. Both kinds of joiners are more likely to have used contraceptives before they joined groups. Thus, selectivity by empowerment and contraceptive-use status has to be taken into account in assessing any program impact, be it for a savings or a credit group.

The analysis of changes in two measures of attitudes, girls' education and delayed marriage, indicates that even after allowing for the differences in levels of empowerment before the program among joiners and nonjoiners, evidence is 
found of women's elevated aspirations for their daughter's education and delayed marriage that may be associated with credit-group membership, but no statistically significant difference exists between savings-group members and those who did not join. The indicators of changing aspirations suggest that although levels of aspirations change, no statistically significant change is seen in the implied gender inequalities in aspirations for daughters and sons.

Other indicators of empowerment such as personal mobility, household decisionmaking, or working for cash did not show appreciable change during the time period the credit programs were in effect. Contraceptive-use levels increased significantly for women in credit groups, but appreciable increases also were found in the use levels among women in savings groups and among nonmembers who lived in the same villages. No appreciable change was seen in contraceptive use in villages where there were no credit-program interventions or other SC development programs.

Rising contraceptive use and aspirations for children's education in the absence of substantial changes in mobility, decisionmaking authority, or the likelihood of working for cash suggest that savings and credit groups affect contraceptive use by increasing women's knowledge and access to contraception and by empowering them to adopt new behaviors, perhaps because discussions among members of the groups gives women confidence to change their behavior because they learn that others are doing so.

Less evidence is found of changing gender dynamics within the household or the community. Contraceptive behavior likely changed in the program villages because the services were already available through the widespread network of family planning clinics and workers in rural Bangladesh. Uptake increased as women formed groups and could give each other the confidence to use modern methods that they may have lacked when they were more isolated within their own homes. 
Future research should focus on the social interactions among group members and their potential for bringing about large-scale social change. Credit groups may work to change behavior by changing village social dynamics substantially in a way that collectively empowers women. Most studies have focused on measures and manifestations of women's empowerment at the individual or household level by means of increased mobility, and greater autonomous decisionmaking. The social changes associated with credit groups, however, may work at a macro level. Some evidence of such change is seen in the increased overall contraceptive-use rates in the program villages.

\section{APPENDIX}

\section{Sample Attrition and Related Biases}

In any panel survey, the problem of attrition is of major concern. In the SC panel survey, 22 percent of women surveyed in 1993 could not be reinterviewed in 1995. For each of these women, the reason for refusal or noncontact was recorded by the interviewer. In 42 percent of attrition cases, the respondent was unavailable at the time of the second interview. Refusal was the second most common reason. Some women had migrated during the intervening period: 10 percent of nonrespondents had migrated permanently and 14 percent were seasonal migrants. Two percent of the original respondents, mainly the oldest women, had died before the 1995 wave of the survey. Attrition is a problem not only because of the resultant reduction in sample size, but also because the sample may be unrepresentative of the target population if dropouts differ systematically from those who remain in the sample. To test for such systematic differences, the authors examined attrition rates for a range of variables from the 1993 survey: age, attendance at school, employment status in the preceding year, several measures of women's empowerment, and area of residence. No significant differences in attrition rates were observed across age groups, although some evidence 
suggests that attrition is slightly higher among women who had been to school. None of the empowerment indicators tested had a significant impact on attrition. The major source of variation in attrition rates is across areas. In particular, response rates are highest in villages in the old intervention area and lowest in the new intervention area. These differences may be due to some variation in datacollection procedures or interviewer effects. An alternative explanation could be that women in the old area are more willing to be reinterviewed because they are accustomed to having their behavior monitored as part of SC's surveillance system. Because the analysis is based on women who respond to both surveys only, controlling for area of residence is necessary to adjust for the effect of attrition bias on the parameter estimates (Little and Rubin, 1987).

\section{Note}

1. The odds ratio for a pair of binary variables is calculated by dividing the product of the diagonal entries in a cross-tabulation of the two variables by the product of the off-diagonal entries. If an odds ratio is equal to 1 , no relationship exists between the variables; a value less than 1 indicates a negative relationship; and a value greater than 1 indicates a positive relationship.

\section{References}

Albanese, M.T. and M. Knott. 1992. "TWOMISS: A computer program for fitting a one- or two-factor logit-probit latent variable model to binary data when observations may be missing." Technical report. London: Statistics Department, London School of Economics and Political Science.

Amin, R., R.B. Hill, and Y. Li. 1995. "Poor women's participation in creditbased self-employment: The impact on their empowerment, fertility, contraceptive use, and fertility desire in rural Bangladesh." The Pakistan Development Review 34: 93-119. 
Amin, Sajeda. 1997. "The poverty-purdah trap in rural Bangladesh: Implications for women's roles in the family." Development and Change 28: 213-233.

Amin, Sajeda and Anne R. Pebley. 1994. "Gender inequality within households: The impact of a women's development program in 36 Bangladeshi villages." The Bangladesh Development Studies 22: 121-54.

Bartholomew, D.J. 1987. Latent Variable Models and Factor Analysis. London: Griffin.

Bongaarts, John and Susan Cotts Watkins. 1996. "Social interactions and contemporary fertility transitions." Population and Development Review 22, 4: 639-682.

Cain, Mead. 1985. "The fate of the elderly in South Asia: Implications for fertility." Paper presented at the IUSSP International Population Conference, Florence, Italy, 5-12 June.

Goetz, A.M. and R.S. Gupta. 1996. "Who takes the credit? Gender, power, and control over loan use in rural credit programs in Bangladesh." World Development 24: 45-63.

Little, R.J.A. and D.B. Rubin. 1987. Statistical Analysis with Missing Data. New York: Wiley.

Maddala, G.S. 1983. Limited Dependent and Qualitative Variables in Econometrics. New York: Cambridge University Press.

Mahmud, S. and S. Huda. 1997. "Group characteristics and individual behavior in low income countries: Are the reported causal relationships the result of heterogeneity bias?" Paper presented at a Population Council workshop on Measuring the Impact of Micro-credit Programs on Fertility, New York.

Mason, K.O. 1986. "The status of women: Conceptual and methodological issues in demographic studies." Sociological Forum: Journal of the Eastern Sociological Society 1: 284-300. 
Mitra, S.N., M.N. Ali, S. Islam, A.R. Cross, and T. Suha. 1994. Bangladesh Demographic and Health Survey 1993-1994. Calverton, MD: National Institute of Population Research and Training, Mitra and Associates, and Macro International.

Montgomery, Mark R. and John Casterline. 1993. "The diffusion of fertility control in Taiwan: evidence from pooled cross-section time series models." Population Studies 47: 457-479.

Montgomery, Mark R. and W. Chung. 1998. "Social networks and the diffusion of fertility control in Korea." In Cultural and Temporal Variations in Values: Impact on Fertility Change. Ed. R. Leete. Oxford: Oxford University Press. Forthcoming.

Naved, R.T. 1997. “The strive for sustainability and its effect on women's participation in a micro-credit program." Report, Save the Children USA, Dhaka.

Pitt, M.M., S.R. Khandker, S. McKernan, and M.A. Latif. 1995. "Credit programs for the poor and reproductive behavior in low income countries: Are the reported causal relationships the result of heterogeneity bias?" Paper presented at the annual meeting of the Population Association of America, San Francisco.

Rahman, Mizanur and Julie DaVanzo. 1995. "Impact of the Grameen Bank on women's status and fertility in Bangladesh." Paper presented at the annual meeting of the Population Association of America, San Francisco.

- 1997. "Influence of the Grameen Bank on contraceptive use in Bangladesh." Paper presented at a Population Council workshop on Measuring the Impact of Micro-credit Programs on Fertility, New York.

Schuler, Sidney Ruth and Syed M. Hashemi. 1994. "Credit programs, women's empowerment, and contraceptive use in rural Bangladesh." Studies in Family Planning 25, 2: 65-76. 
Schuler, Sidney Ruth, Syed M. Hashemi, and A.P. Riley. 1997. "The influence of women's changing roles and status in Bangladesh's fertility transition: Evidence from a study of credit programs and contraceptive use." World Development 25: 563-575.

Sobhan, Rehman. 1995. Experiences with Economic Reform: A Review of Bangladesh's Development 1995. Dhaka: Center for Policy Dialogue and University Press Limited.

Wright, G., M. Hossain, and S. Rutherford. 1997. "Savings: Flexible financial services for the poor." In Who Needs Credit? Poverty and Finance in Bangladesh. Ed. G.D. Wood and I. Sharif. Dhaka: University Press Limited. 


\title{
POLICY RESEARCH DIVISION WORKING PAPERS
}

\author{
Recent Back Issues
}

1996

*83 Sajeda Amin, Ian Diamond, and Fiona Steele, "Contraception and religious practice in Bangladesh."

84 John B. Casterline, Aurora E. Perez, and Ann E. Biddlecom, "Factors underlying unmet need for family planning in the Philippines."

85 Geoffrey McNicoll, "Governance of fertility transition: Regularity and duress."

*86 John Bongaarts, "Population pressure and the food supply system in the developing world."

87 Sajeda Amin, "Family structure and change in rural Bangladesh."

*88 John Bongaarts and Susan Cotts Watkins, "Social interactions and contemporary fertility transitions."
*89 Cynthia B. Lloyd and Mark R. Montgomery, "The consequences of unintended fertility for investments in children: Conceptual and methodological issues."

* 90 Zeba Sathar and Sonalde Desai, "Work patterns in rural Pakistan: Intersections between gender, family, and class."

*91 Mark R. Montgomery, "Learning and lags in mortality perceptions."

92 Ann E. Biddlecom, John B. Casterline, and Aurora E. Perez, "Men's and women's views of contraception."
93 James F. Phillips, Fred N. Binka, Martin Adjuik, Alex Nazzar, and Kubaze Frank Adazu, "The determinants of contraceptive innovation: A case-control study of family planning acceptance in a traditional African society."
94 John Bongaarts and Sajeda Amin, "Prospects for fertility decline and implications for population growth in South Asia."

95 Barbara S. Mensch and Cynthia B. Lloyd, "Gender differences in the

* No longer available 
schooling experiences of adolescents in low-income countries: The case of Kenya."

96 Martin Brockerhoff and Ellen Brennan, "The poverty of cities in the developing world."

97 Carol E. Kaufman, "Reproductive control in South Africa."

98 John Bongaarts, "Trends in unwanted childbearing in the developing world."

99 Mary Arends-Kuenning, "How do family planning workers' visits affect women's contraceptive behavior in Bangladesh?"

100 Mark R. Montgomery and Cynthia B. Lloyd, "Excess fertility, unintended births, and children's schooling."
101 Mary Arends-Kuenning, “The equity and efficiency of doorstep delivery of contraceptives in Bangladesh."

102 Sajeda Amin, Ian Diamond, Ruchira T. Naved, and Margaret Newby, "Transition to adulthood of female factory workers: Some evidence from Bangladesh."

*103 Margaret E. Greene and Ann E. Biddlecom, "Absent and problematic men: Demographic accounts of male reproductive roles."

104 Michael P. Todaro, "Urbanization, unemployment, and migration in Africa: Theory and policy."

105 Geoffrey McNicoll, "Population and poverty: A review and restatement."
106 Sajeda Amin and Gilda Sedgh, "Incentive schemes for school attendance in rural Bangladesh."

107 Martin Brockerhoff and Paul Hewett, "Ethnicity and child mortality in subSaharan Africa."

108 Ann E. Biddlecom and Bolaji M. Fapohunda, "Covert contraceptive use: Prevalence, motivations, and consequences."

109 John Bongaarts and Griffith Feeney, "On the quantum and tempo of fertility."
110 Barbara S. Mensch, Daniel Bagah, Wesley H. Clark, and Fred Binka, "The changing social environment for adolescents in the Kassena-Nankana District of northern Ghana: Implications for reproductive behavior."

111 Martin Brockerhoff and Ann Biddlecom, "Migration, sexual behavior, and HIV diffusion in Kenya."

112 Zeba A. Sathar and John B. Casterline, "The onset of fertility transition in Pakistan." 
113 Geoffrey McNicoll, "Government and fertility in transitional and post-transitional societies."

114 John Bongaarts, "Fertility and reproductive preferences in post-transitional societies."
115 Fiona Steele, Sajeda Amin, and Ruchira T. Naved, "The impact of an integrated micro-credit program on women's empowerment and fertility behavior in rural Bangladesh." 